\title{
HISTOLOGICAL INVESTIGATIONS ON THE THYROID GLANDS OF MARINE MAMMALS (PHOCA VITULINA, PHOCOENA PHOCOENA) AND THE POSSIBLE IMPLICATIONS OF MARINE POLLUTION
}

\author{
U. Schumacher,' S. Zahler, ${ }^{2}$ H.-P. Horny, ${ }^{3}$ G. Heidemann, ${ }^{4}$ \\ K. Skirnisson, ${ }^{5}$ and $U$. Welsch ${ }^{2}$ \\ ' Human Morphology, University of Southampton, England \\ 2 Department of Anatomy, University of Munich, Federal Republic of Germany \\ ${ }^{3}$ Department of Pathology, University of Tübingen, Federal Republic of Germany \\ 4 Unit of Wildlife Biology, University of Kiel, Federal Republic of Germany \\ ${ }^{5}$ Department of Experimental Pathology, University of Iceland, Reykjavik, Iceland
}

ABSTRACT: In 1988 and 1989, thousands of harbor seals (Phoca vitulina) died in the North Sea from phocine distemper infection. The morphology of thyroid glands from $\mathbf{4 0}$ harbor seals found dead on the North Sea coastlines of Schleswig-Holstein, Federal Republic of Germany, during an epizootic of phocine distemper, was compared with the morphology of thyroid glands from five healthy harbor seals collected in Iceland. Thyroid glands from seven harbor porpoises (Phocoena phocoena) found dead in 1990 on the North Sea coastlines also were evaluated. Colloid depletion and fibrosis were found in the thyroid glands of harbor seals which died during the epizootic, but not in animals from Iceland. Thyroid glands of the porpoises showed similar lesions, but to a lesser degree, than those observed in the North Sea seals.

Key words: Phoca vitulina, harbor seal, Phocoena phocoena, harbor porpoise, seal mortality, thyroid lesion.

\section{INTRODUCTION}

During the 1988 and 1989 seal epizootic, nearly 18,000 harbor seals (Phoca vitulina) died in the North, Irish and Baltic Seas (Dietz et al., 1989a). Several pathogens were suspected as causative agents. These include algae and their toxins (Gerlach, 1988), helminths (Breuer et al., 1988), and viruses such as a herpesvirus (Osterhaus, 1988; Horvat et al., 1989; Frey et al., 1989), canine distemper virus (CDV), or a closely related morbillivirus (Osterhaus and Vedder, 1988), now called phocine distemper virus (PDV) (Mahy et al., 1988; Cosby et al., 1988).

Histopathologically, seals which died during the epizootic had a distemper-like infection (Kennedy et al., 1989; Bergman et al., 1990). However, experimental inoculation of beagle dogs permitted serological differentiation of phocine and canine distemper virus, thus indicating that PDV is not identical with CDV (Jäger et al., 1990). Furthermore, antibodies against PDV were detected in seals from Greenland before the onset of the 1984 to 1987 epizootic (Dietz et al., 1989b). Thus, PDV alone might not have caused the mass deaths observed in European seals in 1988 and 1989.

The seal epizootic had a particularly high mortality in those areas where environmental pollution was high (Heidemann, 1989); in contrast, no seal deaths were observed around Iceland, where there is little environmental pollution. Tissues from Iceland seals contained far lower levels of chlorinated hydrocarbons, compared to levels in animals from the North Sea (Luckas et al., 1990). High organochlorine levels have been positively correlated with a high mortality from PDV (Hall et al., 1992). A small number of seals investigated which died during the epizootic in 1988 and 1989 had marked colloid depletion and fibrosis of the thyroid gland. This colloid depletion has been associated with chronic exposure to polychlorinated biphenyls (PCB's) (Schumacher et al., 1990, 1991).

Our objectives in the present study were to compare the structure of thyroid glands from harbor seals which died during the 1988 to 1989 epizootic, to both the thyroid 
glands of harbor seals from Iceland, as well as to the thyroid glands from harbor porpoises (Phocoena phocoena), which live in the same habitats and have similar feeding habits but did not die during the period of the epizootic.

\section{MATERIALS AND METHODS}

Forty-four harbor seal thyroid glands were sampled for the following study. The seals were collected between 1988 and 1990 on the seashores of Schleswig-Holstein, Federal Republic of Germany $\left(53^{\circ} 55^{\prime}\right.$ to $55^{\circ} 05^{\prime} \mathrm{N}, 8^{\circ} 10^{\prime}$ to $\left.10^{\circ} 55^{\prime} \mathrm{E}\right)$ : 36 seals in 1988, four seals in 1989 , four seals in 1990. Thyroid glands from five healthy seals with no antibodies against PDV and CDV were shot on the southeast coast of Iceland $\left(63^{\circ} 05^{\prime}\right.$ to $63^{\circ} 10^{\prime} \mathrm{N}, 15^{\circ} 40^{\prime}$ to $15^{\circ} 45^{\prime} \mathrm{W}$ ) and were used as controls. Absence of antibodies against PDV and CDV were determined by the methods of Harder (1990). Harbor seals with severe autolysis were excluded from the sampling of tissue for this study. To exclude interpretation of artifacts, which may have arisen due to autolysis, autolysis experiments were performed on two of the normal thyroid glands: samples were taken for up to five days post-mortem and analyzed morphologically.

Thyroid glands from seven porpoises which died from causes other than the epizootic and were found on Schleswig-Holstein seashores in 1990 also were evaluated.

Ages of all animals used were estimated by counting the cementum layers of the root of the canine tooth of the upper jaw (Laws, 1950).

Thyroid glands were fixed in $4 \%$ formalin and prepared for wax histology by the methods of Romeis (1968). Hematoxylin and eosin (H\&E), Goldner stains and the periodic acid Schiff (PAS)reaction were used (Romeis, 1968). Colloid depletion was assessed in PAS-stained slides and graded semi-quantitatively from $0=$ normal thyroid; $+=$ grade 1 , slight colloid depletion; $++=$ grade 2 , marked colloid depletion; to $+++=$ grade 3 , almost complete colloid depletion. Goldner-stained slides were subjected to a similar scaling ranging from $0=$ no increase in collagen fibers; $+=$ grade 1 , slight increase in collagen fibers; $++=$ grade 2 , moderate increase in collagen fibers; $+++=$ grade 3 , severe increase in collagen fibers, to estimate the degree of fibrosis. Animals $\leq 1$-year-old were assigned the age of 1 , animals which were 1 to 2 -yr-old the age of 2 , and all animals $\geq 2$ yr old were assigned the age of 3 for the statistical analysis.

Statistical analysis of the data (unpaired $t$-test, one-way analysis of variance differences examined by $t$-test using the pooled standard deviation) was carried out using an in-house statistical package (Norman Version 1.05, by Dr. S. Lawrie, Clinical Pharmacology, University of Southampton, England). The significance level was set at $\alpha=0.05$.

\section{RESULTS}

The five control harbor seals from Iceland had very narrow connective tissue strands between the thyroid follicles (Fig. 1). Their follicles were regular in size and well filled with colloid. In the autolysis experiments no collapse of the follicles or fibrosis was seen.

Seven of the forty seals collected during the 1988 to 1989 epizootic had no signs of colloid depletion, eleven had grade 1 , sixteen had grade 2, and six had grade 3 colloid depletion (Fig. 2). Colloid droplets could be seen in the apical part of the thyroid follicular cells (Fig. 3). In this group, eight animals had no signs of an increased collagen content, ten animals had a grade 1, eighteen animals had a grade 2 and four animals had a grade 3 increase, indicating various degrees of fibrosis (Figs. 3 ,4). Although the amount of collagen deposited varied among different animals, the nature of the collagen was the same in all animals: mature collagen fibrils. No capillaries were found between the fibrils.

One of the four animals collected in Schleswig-Holstein during 1990 had a colloid depletion of grade 1, two had grade 2 and the remaining animal showed no signs of colloid depletion. In this group only one animal showed signs of increased collagen content in the thyroid glands.

There were no significant differences in degree of colloid depletion or collagen content by sex or age of the harbor seals.

Three of the seven porpoises had no colloid depletion and no fibrosis, while four had a grade 1 colloid depletion. Five porpoises had no increase in collagen content and two animals had a grade 2 increase in collagen content. Again, only mature collagen fibrils were observed. 


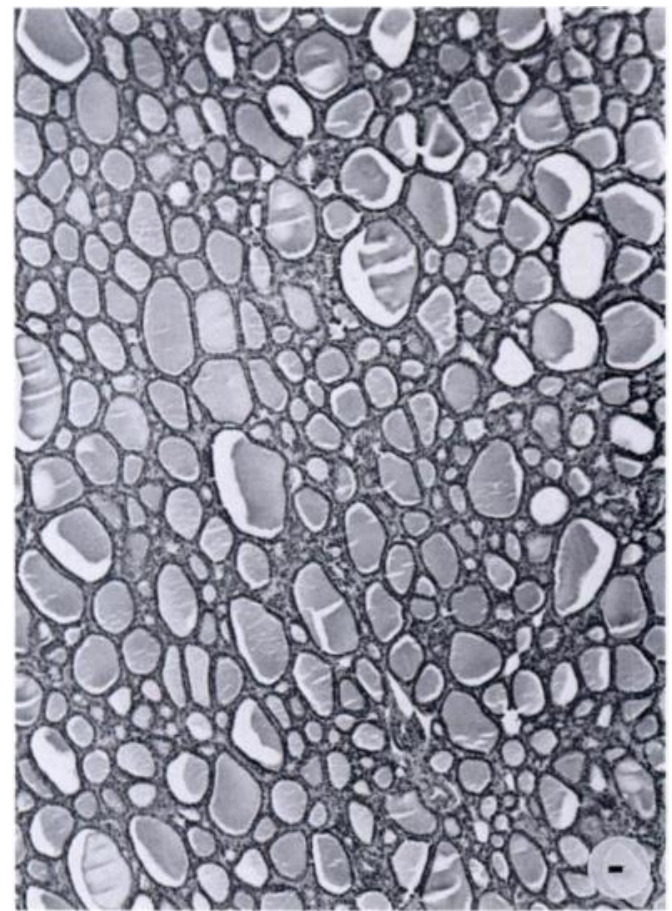

Figure 1. Normal thyroid gland from a harbor seal shot on the coast of Iceland. H\&E. Scale bar $=$ $10 \mu \mathrm{m}$.

\section{DISCUSSION}

Healthy seals from Iceland had thyroid glands with no signs of colloid depletion or an increase in collagen content. In contrast, the thyroid glands of many seals which died during the 1988 to 1989 epizootic had both colloid depletion and an increase in interfollicular collagen content. Some seals which died in 1990 also had colloid depletion but no fibrosis, when compared with the seals from Iceland.

There was a distinct fibrosis of the majority of the thyroid glands from those harbor seals which died during the epizootic. Thyroid glands in southern elephant seals (Mirounga leonina) have no remodelling of the connective tissue within the gland during normal adaptational processes (Little, 1991). Assuming that the thyroid glands of the elephant seals are comparable to those of harbor seals, the fibrosis in the harbor seal probably was a long-standing

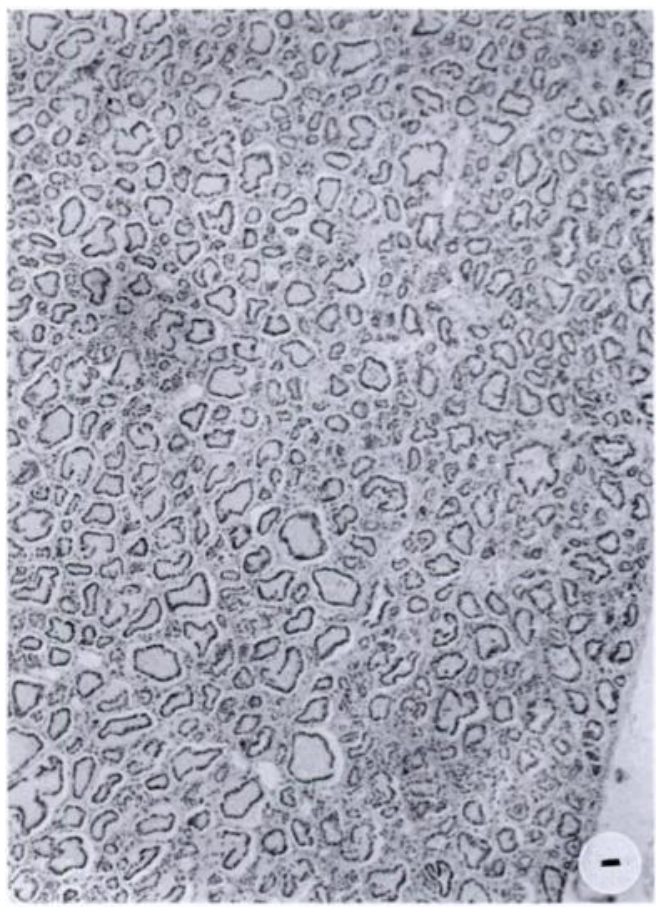

Figure 2. Colloid depletion in the thyroid gland from a harbor seal, which died during the 1988 to 1989 epizootic. H\&E. Scale bar $=10 \mu \mathrm{m}$.

process not attributed to an acute process such as the PDV infection since the fibrosis occurred in the absence of any blood vessels. The process of collagen deposition and reduction of the initial vascularization in the newly formed scar tissue is a process which takes weeks to months (MartinezHernandez, 1988). Since no morphological signs of an increase in the collagen content occurred in our autolysis experiments, artifactual swelling of the connective tissue due to autolysis can be excluded; this is similar to findings on autolysis in the human thyroid gland (Schumacher et al., 1991).

From the present morphological study alone it is difficult to determine whether the fibrosis is due to PCB's. However, the levels of PCB's in seals which died during the epizootic on the German shores were analyzed and were quite high (Luckas et al., 1990). That changes in thyroid function and morphology can be induced by 


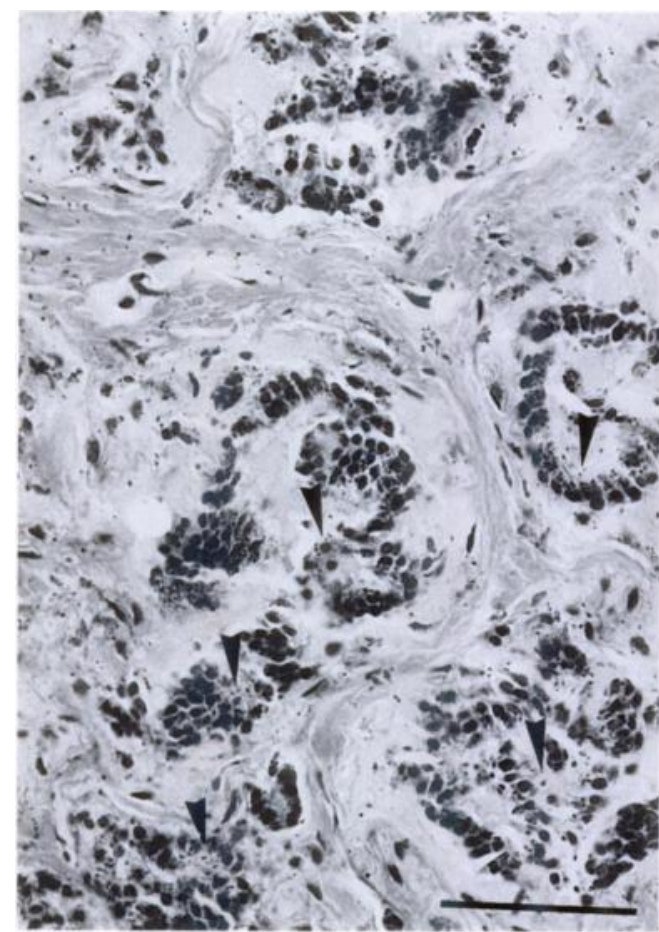

FIc:URE 3. Fibrosis and colloid depletion in the thyroid gland of a seal, which died during the 1988 to 1989 epizootic. Note the intracytoplasmic granules (arrows), which indicate a colloid resorption. Goldner stain. Scale bar $=10 \mu \mathrm{m}$

PCB's has been shown under experimental conditions in rats (Bryne et al., 1987) and seals (Brouwer et al., 1989). That the action of the PCB's is directly on the thyroid is supported by the fact that colloid droplets similar to those found in our samples (Fig. 3) were a characteristic morphological feature of the glandular epithelia in rats fed with PCB's (Collins et al., 1977). Furthermore, feeding harbor seals with PCB-contaminated fish resulted in a decrease of the thyroid hormones as well (Brouwer et al., 1989), indicating that the mode of action on the thyroid gland of PCB's in both species is the same. Therefore it is possible that the colloid depletion of the thyroid follicles and fibrosis of the thyroid gland we observed were caused by chronic PCB intoxication in seals.

The finding that the changes in the thyroid gland of North Sea porpoises were similar to the lesions of North Sea seals

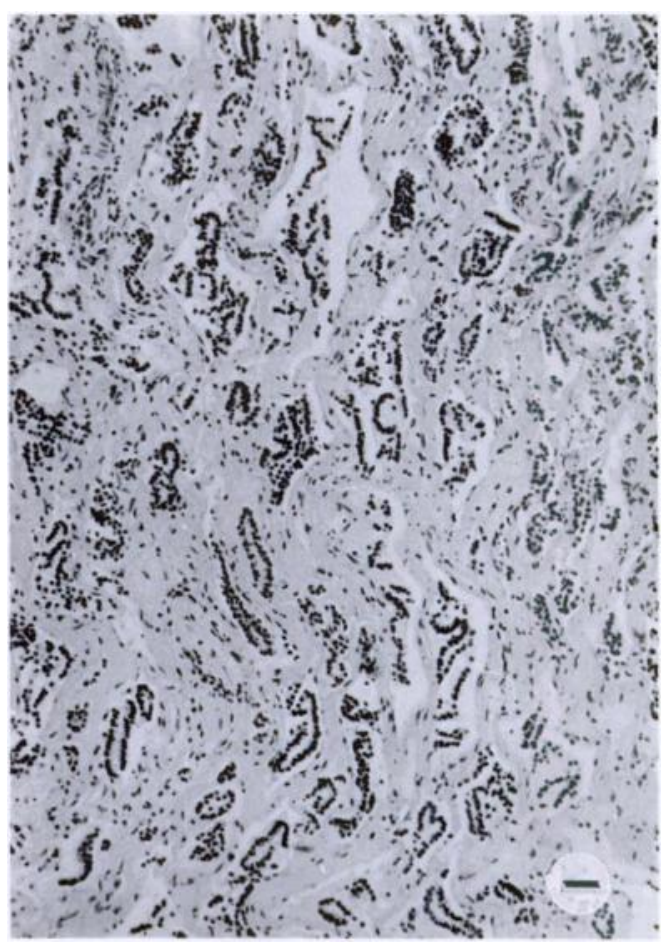

Figure 4. Severe fibrosis and colloid depletion in the thyroid gland of a harbor seal which died during the 1988 to 1989 epizootic. Note the abundance of collagen fibrils and the collapse of the follicles. $\mathrm{H} \& \mathrm{E}$. Scale bar $=10 \mu \mathrm{m}$.

supports the hypothesis that factors common to both species contributed to the alterations observed. Seals and porpoises share the same habitat and food (Corbet and Southern, 1977). Thus, it seems likely that the changes in the morphology of the thyroid gland can be attributed to environmental factors. Since porpoises are more vagrant animals than seals, which may have come from the Atlantic, their diet may have been different, which could account for the lower incidence of thyroid lesions within this group. Another explanation for the higher incidence of thyroid lesions in the seals might be that a select population of seals, namely those which died during the epizootic, was investigated.

\section{ACKNOWLEDGMENTS}

We thank Dr. J. Mitchell for carefully reading the manuscript, Mr. N. Best for carrying out the statistical analysis and the Federal Minister for 
Environment, Nature Conservation and Nuclear Safety for his financial support (Grant number: FKZ 10805 017/09).

\section{LITERATURE CITED}

Bergman, A., B. Järplid, and B.-M. SvensSON. 1990. Pathological findings indicative of distemper in European seals. Veterinary Microbiology 23: 331-341.

Breuer, E. M., R. Hofmeister, R. ERnst, F, HÖRCHNER, AND I. HÖPPNER. 1988. Untersuchungen zum Seehundsterben im Wattenmeer vor Sylt 1988: Bedeutung des hochgradigen Lungenwurmbefalls mit hypersensitiver Reaktion. Journal of Veterinary Medicine, Series B, 35: 467473

Brouwer, A., P. H. J. Reijnders, and J. H. Koeman. 1989. Polychlorinated biphenyl (PCB)-contaminated fish induces vitamin $\mathrm{A}$ and thyroid hormone deficiency in the common seal (Phoca vitulina). Aquatic Toxicology 15: 99-106.

Byrne, J. E., Carbone, J. P., and E. Hanson. 1987. Hypothyroidism and abnormalities in the kinetics of thyroid hormone metabolism in rats treated chronically with polychlorinated biphenyl and polybrominated biphenyl. Endocrinology 121: 520-527.

Collins, W. T., Capen, C. C., Kasza, L., Carter, C., AND R. E. DaILEY. 1977. Effect of polychlorinated biphenyl (PCB) on the thyroid gland of rats. American Journal of Pathology 89: 119136.

Corbet, G. B., And H. N. Solthern. 1977. The handbook of British mammals, 2nd ed. Blackwell Scientific Publications, Oxford, England, 520 pp.

Cosby, S. L., S. MCQuaid, N. DufFy, C. Lyons, B. K. Rima, G. Allan, S. J. McCulloch, S. Kennedy, J. A. Smyth, F. MCNeilly, C. Craig, AND C. ORVELl. 1988. Characterization of a seal morbillivirus. Nature 336: 115-116.

Dietz, R., M.-P. HEIDE-Jø RGENSEN, AND T. HÄRKÖNEN. 1989a. Mass deaths of harbour seals (Phoca vitulina) in Europe. Ambio 18: 258-264.

- C. T. ANSEN, P. HAve, AND M.-P HEIdE-JøRgensen. 1989b. Clue to seal epizootic? Nature 338: 627.

Frey, H.-R, B. Liess, L. HaAs, H. LehmanN, and H.-J. MARSCHALL. 1989. Herpesvirus in harbor seals (Phoca vitulina): Isolation, partial characterization and distribution. Journal of Veterinary Medicine, Series B, 36: 699-708.

Gerlach, S. 1988. Vom Seehundsterben und Algenblüten angeregte Gedanken über pathogene Keime im Phytoplankton und über toxische Effekte von und mit Phytoplankton vergesellschafteten Bakterien. Schriftenreihe des Fischwirtschaftlichen Marketinginstituts 16: 82-109.

Hall, A. J., R. J. Law, D. E. Wells, J. Harwood, H. Ross, S. Kennedy, C. R. Allchin, L. A
Camprell, and P. P. Pomeroy. 1992. Organochlorine levels in common seals (Phoca vitulina) which were victims and survivors of the 1988 phocine distemper epizootic. Science of the total environment. Special issue on phocid distemper, E. Hamilton (ed.). Elsevier Science Publishers, Amsterdam, Netherlands, in press.

HaRder, T. C. 1990. Morbillivirusinfektionen bei Pinnipedia: Untersuchungen zur Charakterisierung, Antigenverwandtschaft und Pathogenität von Morbilliviren phociner Herkunft. DVMThesis. Hannover Veterinary School, Federal Republic of Germany, 177 pp.

Heidemann, G. 1989. Ökologische Probleme des Seehundbestandes. Arbeiten des deutschen Fischerei-Verbandes 48: 76-87.

Horvat, B., T. Willhaus, H. R. Frey, and B. Liess 1989. Herpesvirus in harbour seals (Phoca vitulina): Transmission in homologous host. Journal of Veterinary Medicine, Series B, 36: 715718.

Jäger, M., B. Liess, T. Harder, S. ISing, and M. STOYE. 1990. Experimental inoculation of beagle dogs permits serological differentiation of phocine- and canine distemper virus. Wiener Tierärztliche Monatsschrift 77: 105-108.

Kennedy, S., J. A. Smyth, P. F. Cush, P. Duignan, M. Platten, S. J. McCullolgh, and G. M. ALL.AN. 1989. Histopathologic and immunocytochemical studies of distemper in seals. Veterinary Pathology 26: 97-103.

LAws, R. M. 1950. A new method of age determination in mammals with special reference to the elephant seal (Mirounga leonina, Linn.). Scientific Reports of Falkland Islands Dependencies Survey 2: 1-11.

LiTTLE, G. J. 1991. Thyroid morphology and function and its role in thermoregulation in the newborn southern elephant seal (Mirounga leonina) at Macquarie Island. Journal of Anatomy 176: 55-69.

Luckas, B., W. Vetter, P. Fischer, G. HeidemanN, AND J. PLÖTZ. 1990. Characteristic chlorinated hydrocarbon patterns in the blubber of seals from different marine regions. Chemosphere 21: 1319.

Mahy, B. W. J., T. Barret, S. Evans, E. C. ANderson, AND C. J. BOSTOCK. 1988. Characterization of a seal morbillivirus. Nature 336: 115 .

Martinez-Hernandez, A. 1988. Repair, regeneration and fibrosis. In Pathology, E. Rubin and J. L. Farber (eds.). J. B. Lippincott Company, Philadelphia, Pennsylvania, pp. 36-95.

Osterhaus, A. D. M. E. 1988. Seal death. Nature 334: 301-302.

- AND E. J. VEDDER. 1988. Identification of virus causing recent seal death. Nature 335: 20.

RoMEIS, B. 1968. Histologische Technik, 16th ed. Oldenbourg, München, Federal Republic of Germany, 757 pp. 
SChumaCher, U., H.-P. HoRny, G. HeidemanN, W. SCHUlTZ, AND U. WELSCH. 1990. Histopathological findings in harbour seals (Phoca vitulina) found dead on the German North Sea Coast. Journal of Comparative Pathology 102: 299-309.
WELSCH. 1991. Histological and histochemical investigations into the cause of the recent seal death epidemic. Progress in Histochemistry and Cytochemistry 23: 390-394.

Received for publication 19 November 1991. 